\title{
Identifying the Barriers to Iran's Saffron Export by Using Porter's Diamond Model
}

\author{
Seyed Fathollah Amiri Aghdaie ${ }^{1}$, Mohsen Seidi $^{2} \&$ Arash Riasi $^{1}$ \\ ${ }^{1}$ Faculty of Economics and Administrative sciences, Department of Management, University of Isfahan, Isfahan, \\ Iran \\ 2 Department of Management, Islamic Azad University Mehran Branch, Ilam, Iran \\ Correspondence: Seyed Fathollah Amiri Aghdaie, Faculty of Economics and Administrative sciences, \\ Department of Management, University of Isfahan, Isfahan, Iran. Tel: 98-311-793-5251. E-mail: \\ s.aghdaie@ase.ui.ac.ir
}

Received: May 21, 2012 Accepted: June 6, 2012 Online Published: September 10, 2012

doi:10.5539/ijms.v4n5p129 URL: http://dx.doi.org/10.5539/ijms.v4n5p129

\begin{abstract}
Saffron is an important export product of Iran. Saffron role as an agricultural export product is now obvious worldwide. It is important to identify the barriers to Iran's Saffron export in order to maintain Iran's position as the world's biggest producer and exporter of saffron. The purpose of this study is to determine the barriers to Iran's saffron export to international markets using Michael Porter's Diamond Model.

The type of this paper is empirical and practical and the data collection method is descriptive-cognition. The related information for this scope have been collected by using library resources such as books, scientific journals and moreover, in order to accept or reject the research hypotheses a questionnaire with 42 questions made by researchers have been used. The statistical society of this research includes all the managers, advisors and experts of Iranian saffron export companies.

All the hypotheses of the research were analyzed at the $95 \%$ confidence level. The results show that the most important barriers to Iran's saffron export include the demand conditions, related and supporting industries, firm strategy, structure, and rivalry, government, and chance. The results also indicate that factor conditions are not important barriers to Iran's saffron export.
\end{abstract}

Keywords: saffron, export, the competitive advantage of nations, Porter's diamond model

\section{Introduction}

Nowadays no country is in complete isolation status. The role of the international business in economic development of developing countries has become so important that we can call it the engine of economic growth and development (Goharian, 2000). United Nations Conference on Trade and Development (2004) reported that in order to reduce poverty, the real growth rate of exports for each country should be $5 \%$ per each year. In today's competitive world, the success of each country is related to its understanding from the existing possibilities and opportunities in order to enter the international markets (Haghighat Talab, 2007). Exporting is the most basic entry into international markets. Nowadays countries are trying to use export as an important strategy for development. The expansion of globalization and the accession of countries to WTO have caused a tight international competition for export. From the economical view, export causes national economic development, generates foreign exchange earnings, supports economical activities, and creates job opportunities. From business view, export creates money for reinvestment, causes growth for the company, helps using excess capacity, and let the company to give more profit to its shareholders.

In Iran's case, the expansion of non-oil exports is very important because non-oil exports have a great influence on economic growth (Goharian, 1999). In the agricultural sector, Iranian export products have high quality and reasonable prices. Iran's climate causes good quality for Iranian agricultural products. Iran's agricultural products export from 2001 to 2011 was about $40 \%$ of the country's non-oil exports. The reinforcement of this sector helps Iran to attain self-sufficiency in producing agricultural products; it also generates foreign exchange earnings for the country. Among Iran's agricultural products, Saffron has competitive advantage in production and export. The growth of saffron export share among Iran's non-oil exports and also the role of saffron 
production in villager's employment, are two important reasons for giving more attention to this industry. Therefore, in this study we try to identify the barriers to Iran's saffron export in order to increase the export of this product.

In order to identify the barriers to Iran's saffron export, the researchers have used Porter's diamond model. From the aspect of authors the diamond model is the most comprehensive model in order to identify export barriers, because it considers six major factors that can affect the export of a product,. For example in Resource-Based view (RBV) which was introduced by Wernerfelt (1984), the role of product markets is underdeveloped and the theory has limited prescriptive implications (Priem \& Butler, 2001). Also In dynamic capabilities view which is defined as the firm's ability to integrate, build, and reconfigure internal and external competences to address rapidly changing environments (Teece, Pisano \& Shuen, 1997), the considered factors in these two models can not cover all the circumstances which affect export.

\section{Saffron}

Saffron is a spice derived from the flower of Crocus Sativus. It is also called as health flower, king of spices, and red gold. Saffron is well known for its application in dyeing industries, medicine, and food industries. It is one of the world's most costly spices by weight (Hill, 2004). It is native to Southwest Asia (Grigg, 1974) and was first cultivated in Greece (McGee, 2004). Iran's saffron has been famous as one of Iran's most important non-oil export products because of its fantastic characteristics and its various applications. Iran has been introduced as the world's biggest producer and exporter of high quality saffron from long ago (Islamic Republic of Iran's Center of Export Expansion, 2001). Iran answers for around $90-93 \%$ of global saffron production and exports (Ghorbani, 2008).

Right now, South Khorasan and Razavi Khorasan provinces are the main hubs of saffron cultivation in Iran. Saffron cultivation needs using too much workers that is a good reason for this issue that saffron industry can help to decrease unemployment. Stats show that about 100 thousand families in South Khorasan are employed in saffron industry (Iran's Ministry of Agriculture, 2006). The Food and Agriculture Organization of the United Nations (FAO) announced that the total area under saffron cultivation in the world is 55897 hectares. Among saffron producers, Iran is at the top level with 47208 hectares under saffron cultivation. Table 1 shows the area under saffron cultivation in saffron producing countries. It also indicates that there is a big gap between area under saffron cultivation in Iran and in other saffron producing countries.

Table 1. Area under saffron cultivation in saffron producing countries

\begin{tabular}{ll}
\hline Country name & Area under saffron cultivation in hectares* \\
\hline Iran & 47208 \\
Spain & 4184 \\
India & 2440 \\
Greece & 860 \\
Azerbaijan & 675 \\
Morocco & 500 \\
Italy & 29 \\
Other countries & 1 \\
\hline
\end{tabular}

Notes: * The hectare is a metric unit of area defined as 10000 square meters.

Iranian producers gather 5-7 kilograms saffron from each hectare under saffron cultivation; it can be increased up to 10-12 kilograms per each hectare if they use mechanised machineries and scientific methods. Iran as the biggest saffron producer in the world produces about 100-110 tonnes saffron each year, followed by Spain, India, Greece, Azerbaijan, Morocco and Italy. Iran is also the world's biggest saffron exporter, followed by Spain, Greece, England and Switzerland. Table 2 shows the amount of Iran's saffron production from 2001 to 2011, from the table it can be perceived that Iran's saffron production has been largely decreased in recent years. 
Table 2. Amount of Iran's saffron production from 2001 to 2011

\begin{tabular}{llllllllllll}
\hline Year & 2001 & 2002 & 2003 & 2004 & 2005 & 2006 & 2007 & 2008 & 2009 & 2010 & 2011 \\
\hline $\begin{array}{l}\text { Amount of } \\
\text { production } \\
\text { in tonnes* }\end{array}$ & 152 & 185 & 229 & 220 & 235 & 165 & 148 & 123 & 104 & 112 & 109 \\
\hline
\end{tabular}

Notes: * The tonne is a metric unit of mass equal to 1000 kilograms.

\section{Export}

In International Trade, export refers to selling goods and services produced in the home country to other markets (Joshi, 2005). In national accounts, export consists of transactions in goods and services (sales, barter, gifts or grants) from residents to non-residents (Lequiller \& Blades, 2006). The economic growth of a country is possible when the country is able to generate foreign exchange earnings in order to have a positive balance of trade. The first step to achieve this aim is export development. Export development not only generates foreign exchange earnings but also increases foreign investment, helps to improve infrastructures, decreases the unemployment, helps to develop domestic industries, increases domestic production, increases products quality, and improves living standards. Because of the intense price volatility in the oil market and also because the oil will not be available forever, the expansion of non-oil exports has a great importance for Iran (Rahimi Borujerdi, 1997).

Saffron business is almost monopoly. As discussed, saffron is only produced in few countries, although in recent years more countries have started the cultivation of saffron, Iran is still the biggest exporter of saffron in the world which exports over 100 tonnes saffron each year (The Islamic Republic of Iran Customs Administration, 2010). The major importers of Iran's saffron are UAE and Spain. Spain imports Iranian saffron due to its high quality, although they are the second biggest producer of saffron. Saffron export supply and demand are elastic with respect to export prices (Rezapour \& Mortazavi, 2010).

\section{The Competitive Advantage of Nations}

The Competitive Advantage of Nations theory says that the primary role of a nation is the home base which it provides for the firm. Since firms typically develop within a domestic context prior to expanding internationally, the home base plays a key role in shaping the identity of the firm, the character of its top management and its approach to strategy and organization.

The differences in countries economic structure, cultures, and history affect the international competitiveness of a country. Competitive advantage is defined as the strategic advantage of a business over its rivals in order to have advantage in that industry. Achieving competitive advantage strengthens and positions a business better within the business environment (Rustaa, Daavar, \& Ebrahimy, 2002). In order to achieve competitive advantage, a company should have ideas that best fulfill the market demand. Pricing has also an important role in competition, so the producers should try to decrease the price of their products in order to endure and succeed in competitive scope (Amiri Aghdaie \& Davari, 2010).

\section{Porter's Diamond Model}

Michael Porter is a professor at the Harvard Business School; he is also one of the most active researchers in the field of competition. Porter (1990) developed the diamond model in his book 'The Competitive Advantage of Nations'. Porter has used the diamond model when consulting with the governments of Canada (Porter \& the Monitor Company, 1991) and New Zealand (Crocombe, Enright, \& Porter, 1991). This model evaluates the reasons why particular nations have competitive advantage over their rivals in global competition. As shown in figure 1, Porter's diamond model includes four determinants of national advantage:

- Factor conditions

- Demand conditions

- Related and supporting industries

- $\quad$ Firm strategy, structure, and rivalry 


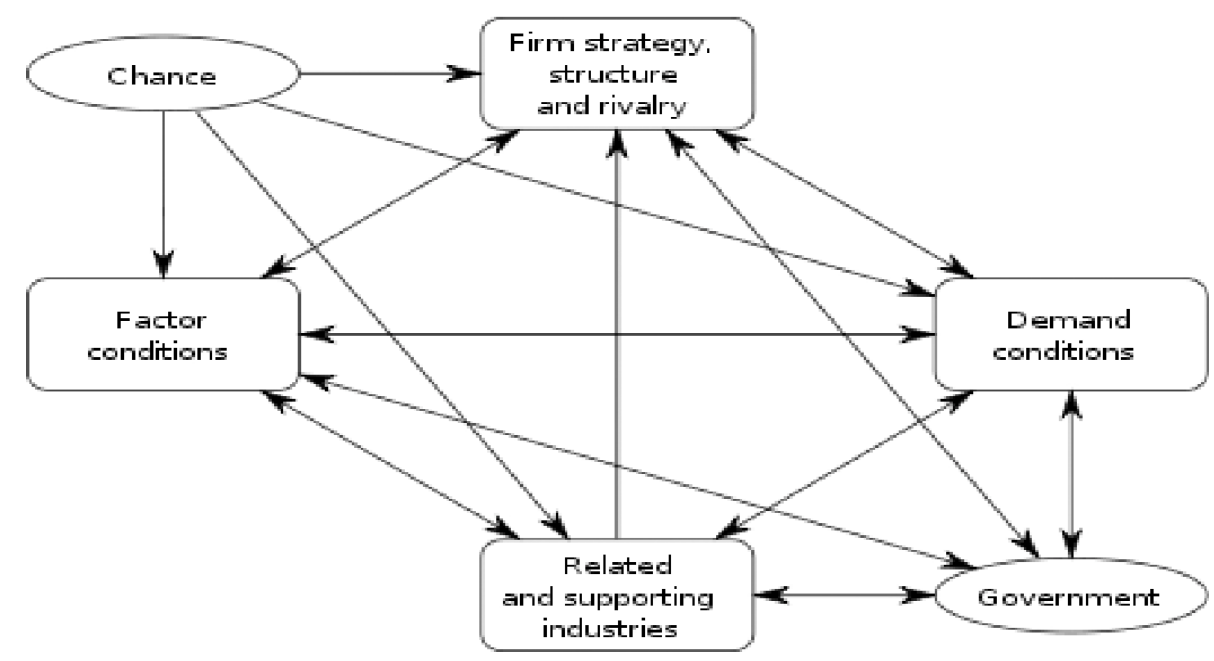

Figure 1. Porter's diamond model

According to Porter (1990) these four determinants mutually affect each other and a change in one of them influences all other three determinants. In addition to these four determinants, government and chance can indirectly influence the competitiveness. The Porter thesis is that these factors interact with each other to create conditions where innovation and improved competitiveness occurs (Traill \& Pitts, 1998). There are some criticisms of Porter's diamond model. Davies and Ellis (2000) believe that sustained prosperity may be achieved without a nation becoming 'innovation-driven', strong 'diamonds' are not in place in the home bases of many internationally successful industries and inward foreign direct investment does not indicate a lack of 'competitiveness' or low national productivity. In Porter's single home-based diamond approach, a firm's capabilities to tap into the location advantages of other nations are viewed as very limited. Rugman(1992) has demonstrated that a much more relevant concept prevails in small, open economies, namely the 'double diamond' model. The double diamond model, developed by Rugman and D'Cruz (1993) suggests that managers build upon both domestic and foreign diamonds to become globally competitive in terms of survival, profitability, and growth.

\subsection{Factor Conditions}

Factor conditions include raw materials, knowledge resources, physical resources, human resources, technological resources, capital resources, infrastructure, innovation power and manager's capabilities. Specialized resources are often specific for an industry and important for its competitiveness. Porter (1990) divides factor conditions into two groups:

- Home-Grown resources such as raw material, energy, and unprofessional human resources.

- Highly specialized resources such as technology, knowledge, and professional human resources.

\subsection{Demand Conditions}

Demand conditions determine the circumstances of domestic demand for products of an industry. Increase in demand has a great influence on competitiveness. Porter (1990) believes that a big growing domestic market encourages the producers to develop technology and efficiency. He believes that this can be a competitive advantage for a nation. In contrast, small domestic markets have a low economic growth rate and therefore they encourage the companies to look for exporting possibilities. Domestic demand has both qualitative and quantitative aspects of market. The size of the domestic demand determines the minimum rate of economic activities of domestic firms and also allows them to have a stable domestic demand. Customer's expectations from the quality of products and services can be an important incentive for the competitiveness of firms or countries.

\subsection{Related and Supporting Industries}

Related and supporting industries include raw materials suppliers, equipment and tools, distributors and retailers, research organizations, product distribution systems, financial organizations such as banks and stock market, transportation systems, and industries which use specific technology, raw materials, and laboratory facilities. 
Having relationship and collaboration with these industries affects the development of products and services, improves the quality of products and services and also helps to increase competitiveness.

\subsection{Firm Strategy, Structure, and Rivalry}

The conditions of the macro level of society and also the way organizations and firms are founded, managed, and organized highly affects competitiveness. Thus, strategies and structure used for managing a firm or an industry has direct influence on performance and competitiveness. In order to have competitive advantage, Porter (1990) suggests public strategies. According to these strategies, a business can achieve competitive advantage in two ways:

- Cost advantage which is providing products and services with lower cost.

- Distinction advantage which is providing various products and services with distinctive features.

Each of these two strategies can create a specific competitive situation for a firm.

\subsection{Government}

Government as a major power can always affect competitiveness positively or negatively by its intervention in politic, economy, and society and also by setting rules. Monetary, financial and business policies, supporting policies, administrative policies, import and export rules, exchange rate, money supply, inflation rate, government costs, macro and micro economics policies, formal and informal political agreements, and establishing or cutting political and economic relations with other countries are the most obvious governmental issues which can affect the competitiveness of firms, industries and countries.

\subsection{Chance}

Events or occurrences that are outside of control of the firms, industries or even governments are called chance. Disasters, wars, economic sanctions, oil shocks, economic or political crises, and great technological innovations are examples of chance.

\section{Background of Research}

Rezapour and Mortazavi (2010) in a study, "Studying globalization impact on export demand and supply of saffron" showed that saffron export supply and demand is elastic with respect to export prices. Also, the impacts of globalization are positive and significant on both demand and supply, indicating the positive effects of increasing trade relations with countries and of removing trade barriers on saffron export supply and demand of Iran

Hosseini and Parmeh (2009) in a study, "Tariff and Non-Tariff barriers to Iran's saffron export" showed that Iran has the highest tariff rate for importing saffron in the world. The research shows that Iran's tariff rate for importing saffron is about 100 percent, the research suggest that the tariff rate of importing saffron should be decreased.

Abbasi (1999) in her study, "Difficulties of Iran's saffron export" showed that Iran's saffron export has been decreased because of lacking correct marketing, lacking suitable packaging and producer's cheatings. Additionally, findings indicate that solving microbial problems of saffron can increase Iran's saffron export.

\section{Methodology}

The goal of this study is to identify the barriers to Iran's saffron export and it intends to help saffron producers in order to export their products into international markets. The type of this paper is empirical and practical and the data collection method is descriptive-cognition. Porter's diamond model has been used in order to identify the barriers to Iran's saffron export. According to the six factors of diamond model, some indexes are defined for Iran's saffron and a questionnaire is created. The research has been done on March 2012 and the statistical society of research includes all the managers, advisors and experts of Iranian saffron export companies. In order to access the statistical society, a list of Iranian saffron exporting companies was created, and the total number of managers, advisors, and experts was counted. The size of the statistical society is 230 . By using convenience sampling, a sample of 55 people was prepared and questionnaires were handed out. The respondents were managers, advisors and experts from different saffron export companies. They were from saffron exporting companies located in Tehran, Isfahan, and Mashhad.

The questionnaire has 42 questions; each statement in the questionnaire is scored on a 9-point Likert scale ranging from 1 to 9 . The questions are designed based on the indexes defined for each of the six factors of Porter's diamond model. 
In order to accept or reject the hypotheses of research, t-test for one society was used with SPSS software. In case the sig (significance level) is less than 0.05 , hypothesis $\mathrm{H} 0$ will be rejected and hypothesis $\mathrm{H} 1$ will be accepted as well as DF shows the degree of freedom. The $t$-test is being done for each hypothesis at the $95 \%$ confidence level.

\section{Data Analysis}

In this part by using mentioned statistical methods and collected information from questionnaires the research hypotheses have been tested.

\subsection{First Hypothesis}

Factor conditions are important barriers to Iran's saffron export into international markets.

H0: Factor conditions are not important barriers to Iran's saffron export into international markets.

H1: Factor conditions are important barriers to Iran's saffron export into international markets.

Because the significance level of 0.05968 is more than 0.05 , hypothesis $\mathrm{H} 1$ is rejected and hypothesis $\mathrm{H} 0$ is accepted at the $95 \%$ confidence level (Table 3 ).

Table 3. First hypothesis at $95 \%$ confidence level

\begin{tabular}{llll}
\hline $\mathrm{T}$ & Average & DF & Sig \\
\hline 16.213 & 4.6833 & 54 & 0.05968 \\
\hline
\end{tabular}

\subsection{Second Hypothesis}

Related and supporting industries are important barriers to Iran's saffron export into international markets.

H0: Related and supporting industries are not important barriers to Iran's saffron export into international markets.

H1: Related and supporting industries are important barriers to Iran's saffron export into international markets.

Because the significance level of 0.00015 is less than 0.05 , hypothesis $\mathrm{H} 0$ is rejected and hypothesis $\mathrm{H} 1$ is accepted at the $95 \%$ confidence level (Table 4.).

Table 4. Second hypothesis at $95 \%$ confidence level

\begin{tabular}{llll}
\hline $\mathrm{T}$ & Average & DF & Sig \\
\hline 29.892 & 6.6923 & 54 & 0.00015 \\
\hline
\end{tabular}

\subsection{Third Hypothesis}

Firm strategy, structure, and rivalry are important barriers to Iran's saffron export into international markets.

H0: Firm strategy, structure, and rivalry are not important barriers to Iran's saffron export into international markets.

H1: Firm strategy, structure, and rivalry are important barriers to Iran's saffron export into international markets.

Because the significance level of 0.00068 is less than 0.05 , hypothesis H0 is rejected and hypothesis H1 is accepted at the $95 \%$ confidence level (Table 5).

Table 5. Third hypothesis at $95 \%$ confidence level

\begin{tabular}{llll}
\hline $\mathrm{T}$ & Average & $\mathrm{DF}$ & Sig \\
\hline 34.397 & 6.6923 & 54 & 0.00068 \\
\hline
\end{tabular}

\subsection{Fourth Hypothesis}

Demand conditions are important barriers to Iran's saffron export into international markets.

H0: Demand conditions are not important barriers to Iran's saffron export into international markets.

H1: Demand conditions are important barriers to Iran's saffron export into international markets. 
Because the significance level of 0.00030 is less than 0.05 , hypothesis $\mathrm{H} 0$ is rejected and hypothesis $\mathrm{H} 1$ is accepted at the $95 \%$ confidence level (Table 6.).

Table 6. Fourth hypothesis at $95 \%$ confidence level

\begin{tabular}{llll}
\hline $\mathrm{T}$ & Average & DF & Sig \\
\hline 21.438 & 7.3500 & 54 & 0.00030 \\
\hline
\end{tabular}

\subsection{Fifth Hypothesis}

Chance is an important barrier to Iran's saffron export into international markets.

H0: Chance is not an important barrier to Iran's saffron export into international markets.

H1: Chance is an important barrier to Iran's saffron export into international markets.

Because the significance level of 0.00019 is less than 0.05 , hypothesis HO is rejected and hypothesis $\mathrm{H} 1$ is accepted at the $95 \%$ confidence level (Table 7.).

Table 7. Fifth hypothesis at $95 \%$ confidence level

\begin{tabular}{llll}
\hline $\mathrm{T}$ & Average & DF & Sig \\
\hline 29.136 & 8.6833 & 54 & 0.00019 \\
\hline
\end{tabular}

\subsection{Sixth Hypothesis}

Government is an important barrier to Iran's saffron export into international markets.

H0: Government is not an important barrier to Iran's saffron export into international markets.

H1: Government is an important barrier to Iran's saffron export into international markets.

Because the significance level of 0.00367 is less than 0.05 , hypothesis H0 is rejected and hypothesis H1 is accepted at the $95 \%$ confidence level (Table 8.).

Table 8 . Sixth hypothesis at $95 \%$ confidence level

\begin{tabular}{llll}
\hline $\mathrm{T}$ & Average & DF & Sig \\
\hline 30.701 & 7.8011 & 54 & 0.00367 \\
\hline
\end{tabular}

\section{Conclusion and Suggestions}

Results show that only the first hypothesis is not supported, all other five hypotheses were significantly supported. Thus, it can be perceived that:

- Factor conditions are not important barriers to Iran's saffron export into international markets.

- Related and supporting industries are important barriers to Iran's saffron export into international markets.

- Firm strategy, structure, and rivalry are important barriers to Iran's saffron export into international markets.

- Demand conditions are important barriers to Iran's saffron export into international markets.

- Chance is an important barrier to Iran's saffron export into international markets.

- Government is an important barrier to Iran's saffron export into international markets.

From the above results it can be concluded that instead of factor conditions, all other factors of Porter's diamond model including demand conditions, related and supporting industries, firm strategy, structure, and rivalry, government, and chance are important barriers to Iran's saffron export. With the use of the collected data from managers, advisors, and experts of Iranian saffron exporting companies, the most important barriers to Iran's saffron export are classified and some solutions are suggested for each barrier. 


\subsection{Solutions for Firm Strategy, Structure, and Rivalry Barrier}

- $\quad$ Providing products and services with lower cost which is known as cost advantage in Porter's Diamond model.

- Providing various products and services with distinctive features which is known as distinction advantage in Porter's Diamond model.

- Privatization of saffron exporting companies and obliging banks to invest in private companies.

- Training managers in order to change their attitude on working at the international level.

- Using appropriate marketing strategies in order to enter international markets with the help of research organizations.

- Adjusting trade liberalization and reforming customs rules.

\subsection{Solutions for Government Barrier}

- $\quad$ Supporting competitiveness between saffron exporters.

- $\quad$ Signing formal and informal trade agreements with countries which have potential markets for saffron, in order to enable saffron exporters to enter new international markets.

- Training governors in order to inform them from the advantages of working at the international markets.

- Informing governors and legislators from the necessity of increasing non-oil exports especially saffron export.

- Informing governors and legislators from the necessity of avoiding single product export.

- Providing political and economic safety, in order to enable companies to set long term missions for expanding their production and exports.

- Reforming rules in order to support foreign investors.

- $\quad$ Providing facilities and financial supports such as giving loans and interest relief.

9.3 Solutions for Related and Supporting Industries Barrier

- Introducing the advantages of investing in Saffron industry to financial organizations such as banks, as it has been asked by saffron exporting companies.

- Having close relationship and collaboration with supporting industries in order to increase the quality of products.

- Comparative study of similar industries in foreign markets.

- Using advanced and updated communication systems, especially internet marketing.

- Involving related industries in saffron export.

9.4 Solutions for Chance Barrier

- $\quad$ Supporting saffron exporters during major economic crises.

- Creating crisis management teams together with the saffron exporters in order to decrease the effects of economic crises on this section.

- Controlling inflation rate in order to prevent the increasing of production factor's cost.

9.5 Solutions for Demand Conditions Barrier

- Helping saffron export companies in order to have a larger domestic market by increasing their product's quality.

- Introducing saffron brands in order to make long term relations with the customers.

- Setting free trade policies for the saffron industry.

- Reducing tariff barriers.

- Increasing the public information about the quality of Iran's saffron.

- Absorbing customer's ideas about their expectations from the products of the company and encouraging them to give suggestions about the quality of the saffron. 


\section{References}

Abbasi, F. (1999). Difficulties of Iran's saffron export. Iran Chamber of Commerce Monthly Journal, 37-42.

Amiri Aghdaie, S. F., \& Davari, H. (2010). Iran Accession to WTO and Its Effects on Food Industries. International Journal of Marketing Studies, 2(2), 160-165.

Crocombe, F. T., Enright, M. J., \& Porter, M. E. (1991). Upgrading New Zealand's competitive advantage. Auckland: Oxford University Press.

Davies, H., \& Ellis, P. (2000), Porter's Competitive Advantage of Nations: Time For The Final Judgement? Journal of Management Studies, 37, 1189-1214. http://dx.doi.org/10.1111/1467-6486.00221

Ghorbani, M. (2008). The Efficiency of Saffron's Marketing Channel in Iran. World Applied Sciences Journal, 4(4), 523-527.

Goharian, M. E. (1999). Managing non-oil exports (2nd ed.). Tehran: Business study and research organization.

Goharian, M. E. (2000). Modern Exports Management. Tehran: Asrare Danesh.

Grigg, D. B. (1974). The Agricultural Systems of the World (1st ed.). Cambridge University Press. http://dx.doi.org/10.1017/CBO9780511665882

Haghighat Talab, M. (2007). Marketing techniques. Tehran: Almase Danesh.

Hill, T. (2004). The Contemporary Encyclopedia of Herbs and Spices: Seasonings for the Global Kitchen (1st ed.). Wiley.

Hosseini, M. A., \& Parmeh, Z. (2009). Tariff and Non-Tariff barriers to Iran's saffron export. Business Reviews, 35(7), 14-31.

Iran's Ministry of Agriculture. (2006). Islamic Republic of Iran yearly agricultural fact book. Tehran: Iran's Ministry of Agriculture.

Islamic Republic of Iran's Center of Export Expansion. (2001). Report about production and export of saffron. Tehran: Islamic Republic of Iran's Center of Export Expansion.

Joshi, R. M. (2005). International Marketing. New Delhi and New York: Oxford University Press.

Lequiller, F., \& Blades, D. (2006). Understanding National Accounts. Paris: OECD.

McGee, H. (2004). On Food and Cooking: The Science and Lore of the Kitchen. Scribner.

Porter, M. E. (1990). The Competitive Advantage of Nations. New York, NY: The Free Press.

Porter, M. E., \& the Monitor Company (1991). Canada at the crossroads: The reality of a new competitive environment. Ottawa: Business Council on National Issues and Minister of Supply and Services of the Government of Canada.

Priem, R. L., \& Butler, J. E. (2001). Is the Resource-Based Theory a Useful Perspective for Strategic Management Research? Academy of Management Review, 26(1), 22-40.

Rahimi Borujerdi, A. (1997). Exchange Rate and Non-Oil Export. Tehran: Banking and Monetary Researches Organization Press.

Rezapour, S., \& Mortazavi, S. A. (2010). Studying globalization impact on export demand and supply of saffron. Agricultural Economics: Iranian Journal of Agricultural Economics, 4(3), 153-170.

Rugman, A. M. (1992). Porter takes the wrong turn. Business Quarterly, 56(3), 59-64.

Rugman, A. M., \& D'Cruz, J. R. (1993). The double diamond model of international competitiveness: Canada's experience. Management International Review, 33(2), 17-39.

Rustaa, A., Daavar V., \& Ebrahimy A. H. (2002). Marketing Management. Tehran: Samt publication.

Teece, D. J., Pisano, G., \& Shuen A. (1997). Dynamic Capabilities and Strategic Management. Strategic Management Journal (John Wiley \& Sons), 18(7), 509-533.

The Islamic Republic of Iran Customs Administration. (2010). Iran's Foreign Business Annual Report. Tehran: IRICA.

Traill, W. B., \& Pitts, E. (1998). Competitiveness in the Food Industry. Springer.

United Nations Conference on Trade and Development. (2004). World Investment Report: The Shift towards Services. New York and Geneva: United Nations. 
Wernerfelt, B. (1984). The Resource-Based View of the Firm. Strategic Management Journal, 5(2), 171-180. http://dx.doi.org/10.1002/smj.4250050207 